\title{
Mekanisme Pengungkapan Emisi Karbon dan Reaksi Investor
}

\author{
Chen Kelvin ${ }^{1}$ \\ Oktavianus Pasoloran ${ }^{2}$ \\ Fransiskus Randa ${ }^{3}$ \\ ${ }^{1,2,3}$ Fakultas Ekonomi, Universitas Atma Jaya Makassar, Indonesia \\ email:chenk194@gmail.com
}

DOI: https://doi.org/10.24843/JIAB.2019.v14.i02.p02

\section{Jurnal Ilmiah Akuntansi dan Bisnis (JIAB)}

https://ojs.unud.ac.id/index.php/jiab/ user/profile

Volume 14

Nomor 2

Juli 2019

Halaman 155-168

p-ISSN 2302-514X

e-ISSN 2303-1018

\section{INFORMASI ARTIKEL}

Tanggal masuk:

08 Maret 2019

Tanggal revisi:

18 Mei 2019

Tanggal terima:

27 Juni 2019

\begin{abstract}
ABSTRAK
Penelitian bertujuan menginvestigasi peran pengungkapan emisi karbon sebagai mekanisme untuk meningkatkan reaksi investor dalam bentuk abnormal return saham yang dimediasi oleh biaya ekuitas. Sampel yang digunakan dalam penelitian adalah perusahaan non-keuangan yang terdaftar di Bursa Efek Indonesia dari tahun 2013 sampai dengan 2017. Jumlah sampel penelitian sebanyak 122 perusahaan dengan jumlah pengamatan adalah 610 sampel. Penelitian menggunakan teknik purposive sampling. Hasil penelitian dengan menggunakan analisis jalur menunjukkan bahwa pengungkapan emisi karbon memiliki hubungan negatif dan signifikan terhadap biaya ekuitas dan pengungkapan emisi karbon memiliki hubungan positif dan signifikan terhadap abnormal return saham serta biaya ekuitas memiliki hubungan negatif dan signifikan terhadap abnormal return saham. Selain itu, hasil pengujian Sobel menunjukkan bahwa biaya ekuitas memiliki peran dalam memediasi pengungkapan emisi karbon terhadap abnormal return saham.
\end{abstract}

Kata kunci: Pengungkapan emisi karbon, biaya ekuitas, abnormal return saham

\section{Carbon Emission Disclosure Mechanisms and Investor Reactions}

\begin{abstract}
This research aims to investigate the role of carbon emission disclosure as a mechanism to improve investors' reaction to abnormal stock returns mediated by cost of equity. The samples used in this study were non-financial companies listed on the Indonesia Stock Exchange from 2013 to 2017. There were 122 companies with 610 observations. The samples were selected using the purposive sampling method. By using the path analysis method, the results show that carbon emission disclosure has a negative relationship with the cost of equity, carbon emission disclosure has a positive relationship with abnormal stock return, while the cost of equity has a negative and significant relationship with abnormal stock return. Additionally, the results obtained using the Sobel test show that the cost of equity plays a role in mediating the relationship between carbon emission disclosure and abnormal stock returns. Keywords: Carbon emission disclosure, cost of equity, abnormal stock returns
\end{abstract}

\section{PENDAHULUAN}

Pasar modal merupakan alternatif investasi yang diminati oleh investor karena adanya peluang untuk mendapatkan keuntungan dari investasi atau biasa disebut dengan keuntungan saham. Semakin suatu saham diminati oleh investor maka harga saham tersebut semakin terpengaruh dan akan menimbulkan abnormal return saham (Cordeiro dan Tewari, 2015). Hal ini menunjukkan bahwa abnormal return berperan sebagai indikator seberapa besar minat dan respon pasar terhadap saham perusahaan.

Salah satu pendorong pasar yang dapat membuat harga saham bergerak dan berdampak pada return saham yaitu pengungkapan emisi karbon 
pada laporan tahunan perusahaan. Laporan yang transparan dan rinci tentang tanggung jawab lingkungan perusahaan khususnya emisi karbon menjadi sangat penting bagi investor dan pemangku kepentingan lainnya karena merasionalisasi ekspektasi mereka terhadap keberlanjutan suatu perusahaan (Gray, 2010; Liao et al., 2015; Meng, et al., 2014). Keuntungan ini memungkinkan perusahaan untuk meningkatkan posisi kompetitif di pasar sehingga terjadi kenaikan harga saham yang melebihi return yang diekpektasikan oleh investor (Liao et al., 2015).

Pengungkapan emisi karbon juga dapat menjadi suatu corporate action yang baik dalam rangka menjaga keseimbangan sistem kehidupan yang ada di Bumi. Teori Gaia yang dikemukakan oleh Lovelock (1979) menyatakan bahwa meskipun bumi memiliki kemampuan metabolisme dalam mereduksi dan menyembuhkan lukanya sendiri, namun fenomena pemanasan global akibat tingginya kandungan gas rumah kaca di atmosfer ternyata tidak mampu direduksi secara cepat oleh tumbuhtumbuhan dan fitoplankton-fitoplankton yang berada di muka bumi saat ini. Oleh karena itu, orang-orang di bumi harus segera memberikan respon terhadap ancaman dan risiko perubahan iklim terhadap lingkungan sekitar (Choi, et al., 2013).

Perusahaan yang mengungkapkan informasi emisi karbon cenderung akan menerapkan prinsip sustainability ke dalam strategi dan operasi perusahaan sehingga investor diharapkan dapat mempertimbangkan informasi karbon sebagai bahan pengambilan keputusan investasi (Kelvin et al., 2017; Park et al., 2014). Apabila informasi emisi karbon dipertimbangkan oleh investor maka terjadi kenaikan harga saham yang melebihi return yang diekspektasikan oleh investor sehingga pada akhirnya informasi emisi karbon merupakan informasi yang memberikan nilai tambah bagi investor dan mengakibatkan abnormal return saham.

Indeks SRI KEHATI pada Bursa Efek Indonesia (BEI) menunjukkan adanya peningkatan harga saham 10 persen lebih tinggi pada 25 emiten yang berkomitmen pada pengurangan emisi karbon (Tempo.co, 2013). Bahkan, hingga akhir Oktober 2017 , indeks ini telah tumbuh 17,19 persen menggungguli Indeks Harga Saham Gabungan (IHSG) yang hanya tumbuh 13,39 persen (Tribunnews.com, 2017). Fenomena ini menunjukkan informasi emisi karbon mampu memberikan keyakinan pada stakeholder atas prospek perusahaan yang sustainable di masa yang akan datang. Corporate action perusahaan yang tinggi ini selanjutnya akan direspon positif oleh para pelaku pasar sehingga terjadi kenaikan harga saham yang melebihi return yang diekspektasikan oleh investor.

Respon terhadap ancaman yang ditimbulkan dari perubahan iklim telah menjadi perhatian dari dunia usaha dan menjadi bagian integral dari bisnis. Pengungkapan emisi karbon dapat digunakan sebagai salah satu cara perusahaan untuk mengomunikasikan tindakan keberlanjutan yang telah dilakukan perusahaan dalam rangka meminimalisir efek gas rumah kaca. Namun, sejumlah perdebatan akademis terkait hubungan pengungkapan emisi karbon dan abnormal return saham masih tidak konsisten dan bervariasi tergantung pada wilayah (negara) pengungkapan. Oleh karena itu, penelitian ini menyediakan kerangka penelitian yang lebih komprehensif untuk menginvestigasi apakah fokus perusahaan pada keberlanjutan seperti pengungkapan emisi karbon mampu mendorong kinerja bisnis yang lebih baik dan mampu memberikan hasil nyata kepada investor dalam bentuk abnormal return saham.

Perbedaan penelitian ini dengan penelitian sebelumnya terletak pada penambahan variabel mediasi biaya ekuitas yang menggambarkan risiko investasi yang dimiliki oleh perusahaan. Komitmen perusahaan dalam mengurangi emisi karbon membantu perusahaan mendapatkan kepercayaan dari stakeholder bahwa perusahaan ikut serta dalam menjaga kelangsungan hidup ekosistem alam dan kondisi kehidupan generasi sekarang dan mendatang. Selain itu, kepercayaan stakeholder juga diharapkan meningkat karena perusahaan melindungi kepentingan stakeholder melalui strategi dan operasi yang sustainable. Dengan demikian, pengungkapan emisi karbon diharapkan dapat menjadi goodnews bagi investor bahwa risiko investasi di perusahaan rendah, sehingga akan menghasilkan biaya ekuitas perusahaan yang rendah. Dengan demikian, investor akan cenderung mempertahankan investasi mereka di perusahaan bahkan menambah investasi sehingga terjadi kenaikan harga saham yang melebihi imbal hasil yang diekpektasikan oleh investor (abnormal return saham).

Pentingya penelitian ini terletak pada abnormal return saham yang menggambarkan seberapa besar reaksi investor terhadap sustainable corporate action perusahaan. Pengungkapan emisi karbon dapat menjadi sinyal kepada investor bahwa perusahaan telah mengelola investasi yang telah diberikan dengan baik. Variabel biaya ekuitas sebagai variabel mediasi akan meyakinkan para investor bahwa investasi yang diberikan tidak sia-sia karena perusahaan memiliki risiko lingkungan yang rendah 
dan senantiasa menjaga nama baiknya sebagai perusahaan ramah lingkungan. Dengan demikian, harga saham diharapkan semakin meningkat yang diikuti dengan kenaikan pembelian saham sehingga terjadi kenaikan harga saham yang melebihi return yang diekpektasikan oleh investor (abnormal return saham).

Penelitian hubungan pengungkapan emisi karbon dan biaya ekuitas telah dilakukan oleh Michaels dan Grüning (2017) yang menunjukkan perusahaan yang secara sukarela mengungkapkan emisi karbon akan menerima kompensasi penurunan biaya ekuitas. Kelvin et al. (2017) dan Gupta (2018) juga menemukan hasil bahwa pengungkapan lingkungan yang dilakukan perusahaan secara signifikan berhubungan negatif dengan informasi asimetri dan biaya ekuitas. Namun, Dhaliwal et al., (2011) menyatakan pengungkapan karbon belum menjamin biaya ekuitas rendah karena perusahaan berkinerja lingkungan buruk juga mencoba untuk mengungkapkan lebih banyak untuk mempertahankan legitimasi.

Penelitian hubungan pengungkapan emisi karbon dan abnormal return saham dilakukan Ramírez et al., (2016) yang menyatakan publikasi laporan Carbon Disclosure Project (CDP) mengakibatkan pergerakan harga saham yang jauh lebih tinggi dibandingkan dengan yang dihasilkan oleh perusahaan yang tidak berpartisipasi dalam laporan CDP. Li dan Wu (2017) menemukan pengumuman lingkungan berhubungan negatif signifikan terhadap abnormal return saham untuk perusahaan di industri yang berbeda.

Li, et al., (2013) menyatakan biaya ekuitas berpengaruh signifikan terhadap tingkat pengembalian yang diharapkan investor berdasarkan waktu, baik dalam satu bulan hingga empat tahun. Namun, Larocque dan Lyle (2017) tidak menemukan adanya hubungan antara biaya ekuitas dan return saham. Biaya ekuitas dipandang tidak memberikan informasi return saham secara inkremental karena kurangnya hubungan dengan return akuntansi masa depan.

Teori stakeholder membentuk filosofi manajemen dengan merekomendasikan sikap, struktur, dan praktik agar manajemen perusahaan dapat mengelola kepentingan seluruh pihak secara seimbang (Donaldson dan Preston, 1995). Keberadaan suatu perusahaan juga sangat dipengaruhi oleh dukungan yang diberikan stakeholder kepada perusahaan. Semua stakeholder termasuk alam semesta, masyarakat dan generasi mendatang (Zsolnai, 2006) mempunyai hak memperoleh informasi mengenai aktivitas perusahaan yang dapat memengaruhi proses pengambilan keputusan (Gray et al.,1995).
Teori Gaia yang dikemukakan oleh Lovelock (1979) semakin mempertegas unsur-unsur stakeholder yang wajib diperhatikan perusahaan. Tingkat pencemaran karbon dioksida yang semakin meningkat sebagai akibat dari perkembangan industri akan mendorong perusahaan untuk saling menjaga harmoni dan stabilitas sistem kehidupan bumi dengan cara memelihara, menjaga dan melestarikan lingkungan hidup yang bukan semata-mata demi kepentingan manusia, tetapi juga harus menghormati unsur pendukung bumi yang lain, seperti tanah, udara, lautan, dan semua komponennya baik yang hidup maupun tidak.

Teori stakeholder dan teori Gaia sangat tepat dalam menggambarkan motivasi di balik keputusan perusahaan publik mengungkapkan informasi emisi karbon. Hal ini dianggap sebagai salah satu bukti bahwa entitas dapat proaktif menegaskan pengaruhnya kepada para stakeholder. Selain itu, pengungkapan emisi karbon juga dapat dijadikan sinyal positif atau kabar baik bagi investor dan para stakeholder bahwa perusahaan serius dalam menghadapi masalah lingkungan yang terjadi (Odriozola dan Baraibar-Diez, 2017). Hal ini sejalan dengan signalling theory yang menekankan pentingnya informasi yang dikeluarkan oleh perusahaan terhadap keputusan investasi pihak di luar perusahaan.

Sinyal pengungkapan emisi karbon akan mencerminkan etika bisnis yang dijalankan perusahaan (Alvarez et al., 2015). Komitmen perusahaan dalam mengurangi emisi karbon membantu perusahaan mendapatkan kepercayaan stakeholder bahwa perusahaan turut serta bertanggungjawab terhadap lingkungan. Oleh karena itu, jika perusahaan senantiasa menjaga kelangsungan hidup ekosistem alam dan kehidupan generasi sekarang dan mendatang, maka mereka mampu menciptakan reputasi positif bagi perusahaan (Odriozola dan Baraibar-Diez, 2017).

Adanya good news pengungkapan emisi karbon akan memberikan keyakinan yang tinggi bagi investor untuk berinvestasi sehingga membuat biaya ekuitas yang disyaratkan investor terhadap perusahaan menjadi lebih rendah (Kelvin et al., 2017). Hal ini disebabkan biaya ekuitas berkaitan dengan risiko investasi atas saham perusahaan. Semakin tinggi risiko investasi yang dihadapi investor, semakin tinggi pula permintaan biaya ekuitas. Sebaliknya, apabila risiko penanaman modal investor rendah akan membuat biaya ekuitas menjadi semakin rendah. Informasi yang baik akan mengakibatkan rendahnya biaya ekuitas karena adanya keselarasan antara 
peluang investasi dan investasi pilihan (Lambert et al., 2007).

Konsep dari biaya ekuitas juga digunakan untuk menghitung tingkat pengembalian hasil atas saham biasa yang diinginkan oleh para investor. Penurunan biaya ekuitas yang disebabkan adanya goodnews yang diterima investor akan menurunkan tingkat risiko investasi perusahaan. Dengan demikian, kepercayaan investor meningkat akan kemampuan perusahaan mengelola modal sehingga investor akan menanggapi informasi yang baik dengan menanamkan modalnya sehingga akan terjadi perubahan harga saham. Perubahan harga saham akan meningkatkan keuntungan saham yang diperoleh. Tingkat keuntungan maupun penurunan saham dapat diukur melalui abnormal return.

Berdasarkan penjelasan di atas, maka dapat disusun kerangka pemikiran teoritis yang menyatakan hubungan antar variabel atas dasar teori stakeholder, teori sinyal, dan teori gaia serta penelitian-penelitian sebelumnya dan rasionalisasi sebagai berikut :

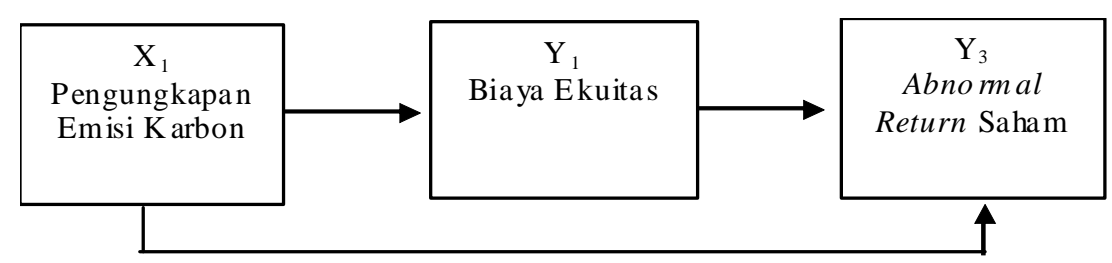

Sumber: Data diolah, 2018

\section{Gambar 1. Kerangka Pemikiran Teoritis}

Michaels dan Grüning (2017) menyatakan perusahaan yang secara sukarela mengungkapkan emisi karbon akan menerima kompensasi penurunan biaya ekuitas. Kelvin et al. (2017) dan Gupta (2018) juga menemukan bahwa perusahaan dengan pengungkapan lingkungan yang tinggi akan menikmati cost of equity yang lebih rendah. Hasil penelitian berbeda ditemukan Dhaliwal et al. (2011) yang menunjukkan pengungkapan emisi karbon tidak berpengaruh terhadap biaya ekuitas karena beberapa investor memandang perusahaan berkinerja lingkungan buruk juga mencoba mengungkapkan emisi karbon untuk mempertahankan legitimasi sehingga belum menjamin biaya ekuitas menjadi lebih rendah.

Teori sinyal yang dikemukakan Spence (1973) menjelaskan bahwa dalam situasi asimetri informasi, investor memerlukan sinyal dari perusahaan. Pengungkapan emisi karbon yang lebih besar dapat menjadi sinyal untuk mengurangi asimetri informasi antara manajer dan investor. Semakin baik informasi yang disampaikan maka semakin kecil tingkat risiko yang dihasilkan. Dengan demikian, sesuai prinsip high risk - high return, maka risiko investasi yang rendah akibat adanya pengungkapan informasi emisi karbon akan menghasilkan biaya ekuitas perusahaan yang rendah pula. Berdasarkan hal tersebut, maka peneliti merumuskan hipotesis sebagai berikut :

$\mathrm{H}_{1}$ : Pengungkapan emisi karbon berpengaruh signifikan terhadap biaya ekuitas.
Ramírez et al. (2016) menyatakan publikasi laporan Carbon Disclosure Project (CDP) mengakibatkan pergerakan harga saham yang jauh lebih tinggi dibandingkan dengan yang dihasilkan oleh perusahaan yang tidak berpartisipasi dalam laporan CDP. Liesen, et al., (2017) juga menyatakan bahwa investor mencapai abnormal risk-adjusted returns hingga 13,05 persen setiap tahun dengan mengeksploitasi efek positif dari pengungkapan emisi GRK dan kinerja perubahan iklim perusahaan yang baik dalam hal efisiensi gas rumah kaca. Namun, Li dan $\mathrm{Wu}$ (2017) menemukan bahwa pengumuman ramah lingkungan perusahaan Cina berhubungan negatif signifikan terhadap return saham.

Teori stakeholder menyatakan bahwa nasib dan kelangsungan hidup ekosistem alam serta kondisi kehidupan generasi sekarang dan mendatang sangat dipengaruhi oleh aktivitas bisnis yang dijalankan oleh perusahaan (Zsolnai, 2006). Bisnis yang berkelanjutan tentu dapat terpenuhi apabila perusahaan dapat mensejahterakan seluruh stakeholdernya (Freeman, 1984). Selain itu, Teori Gaia yang dikemukakan oleh Lovelock (1979) juga mendorong perusahaan untuk melandaskan strategi dan operasional perusahaan yang bukan hanya memanfaatkan alam demi keuntungan diri sendiri (manusia) semata, tetapi strategi dan operasional yang mempunyai tanggung jawab untuk terus memelihara keseimbangan alam sebagai bagian dari tanggung jawab sistem kehidupan global bumi. 
Perusahaan dapat menunjukkan keterampilan pengelolaan gas rumah kaca terbaik yang telah dilakukan melalui pengungkapan emisi karbon. Sistem kontrol dan manajemen lingkungan yang berkualitas dapat menjadi sinyal yang meyakinkan investor untuk melakukan investasi saham. Dengan demikian, kemampuan berkelanjutan perusahaan di masa datang mengakibatkan pasar menjadi tidak efisien dan terjadi kenaikan harga saham yang melebihi return yang diekpektasikan oleh investor (abnormal return saham). Berdasarkan penjelasan di atas, maka peneliti merumuskan hipotesis sebagai berikut :

$\mathrm{H}_{2}$ : Pengungkapan emisi karbon berpengaruh signifikan terhadap abnormal return saham.

Li et al. (2013) menyatakan biaya ekuitas berpengaruh signifikan terhadap tingkat pengembalian investor berdasarkan waktu, baik itu dalam satu bulan hingga empat tahun. Namun, Larocque dan Lyle (2017) tidak menemukan adanya hubungan antara biaya ekuitas dan return saham di masa datang. Biaya ekuitas dipandang tidak memberikan informasi return saham inkremental karena kurangnya hubungan dengan return akuntansi masa depan.

Harrison dan Wicks (2013) dalam teori stakeholder menyatakan tugas utama dari manajer perusahaan ialah menyediakan return maksimal yang memungkinkan kepada pemegang saham. Manajemen perusahaan harus dapat mengelola dan memanfaatkan dengan baik seluruh sumber daya yang dimiliki perusahaan sehingga dapat meningkatkan kesejahteraan stakeholder yang diwujudkan dengan meningkatnya return saham.

Tingginya harga saham memperlihatkan bahwa kinerja perusahaan baik. Hal ini akan membuat investor menurunkan biaya ekuitas karena kinerja perusahaan yang baik mengartikan risiko investasi yang rendah. Penurunan dari biaya ekuitas akan meningkatkan abnormal return sebab abnormal return merupakan selisih antara actual return dengan expected return yang mencerminkan biaya ekuitas perusahaan. Berdasarkan penjelasan di atas, maka peneliti merumuskan hipotesis sebagai berikut: $\mathrm{H}_{3}$ : Biaya ekuitas berpengaruh signifikan terhadap abnormal return saham.

Biaya ekuitas merupakan faktor yang dapat memengaruhi abnormal return saham. Tingginya harga saham akan membuat investor menurunkan biaya ekuitas karena kinerja perusahaan yang baik mengindikasikan risiko investasi yang rendah (Gupta, 2018; Li et al., 2013). Perusahaan yang peduli terhadap lingkungan cenderung akan mengirimkan sinyal keunggulan kompetitifnya kepada investor sehingga menjadi daya tarik bagi investor untuk menanamkan modalnya pada saham perusahaan. Investor yang mendapatkan sinyal bahwa perusahaan memiliki risiko investasi rendah akan segera memberikan respon yang positif, sehingga terjadi kenaikan harga saham yang melebihi return yang diekpektasikan oleh investor (abnormal return saham).

Teori stakeholder menyatakan bahwa nasib dan kelangsungan hidup ekosistem alam serta kondisi kehidupan generasi sekarang dan mendatang sangat dipengaruhi oleh aktivitas bisnis yang dijalankan oleh perusahaan (Zsolnai, 2006). Setiap perusahaan juga diharapkan memiliki kesadaran untuk menjaga dan melestarikan lingkungan hidup yang bukan sematamata demi kepentingan manusia, tetapi merupakan bagian dari tanggung jawab sistem kehidupan di bumi (Lovelock, 1979). Oleh karena itu, pengungkapan emisi karbon dapat menjadi sinyal yang baik bagi stakeholder bahwa perusahaan turut berkomitmen menjaga kondisi kehidupan bumi dari ancaman perubahan iklim.

Sistem kontrol dan manajemen lingkungan perusahaan yang terwujud dalam pengungkapan emisi karbon diharapkan dapat memberikan goodnews bagi investor bahwa perusahaan mampu mengelola risiko lingkungannya dengan baik. Risiko yang rendah dalam bentuk biaya ekuitas yang rendah juga akan memberikan keyakinan bagi investor bahwa investasi yang diberikan tidak sia-sia dan dapat menjadi sinyal positif bahwa imbal hasil yang didapatkan investor akan semakin meningkat. Hal ini mengakibatkan investor maupun investor potensial ingin menanamkan modal di perusahaan, sehingga terjadi kenaikan harga saham yang melebihi return yang diekpektasikan oleh investor (abnormal return saham). Berdasarkan penjelasan di atas, maka peneliti merumuskan hipotesis sebagai berikut :

$\mathrm{H}_{4}$ : Biaya ekuitas memediasi hubungan pengungkapan emisi karbon dan abnormal return saham.

\section{METODE PENELITIAN}

Populasi dalam penelitian merupakan perusahaan publik yang terdaftar di Bursa Efek Indonesia (BEI) selama periode 2013-2017. Sampel perusahaan yang digunakan dalam penelitian ini dipilih dengan metode purposive sampling dengan kriteria perusahaan non keuangan yang terdaftar di BEI dan menerbitkan laporan tahunan lengkap selama periode 2013-2017 serta perusahaan mengungkapkan minimal satu kebijakan yang terkait dengan emisi karbon atau gas 
rumah kaca. Jenis data yang digunakan dalam penelitian adalah data dokumenter berupa laporan tahunan perusahaan yang terdaftar di Bursa Efek Indonesia periode 2013-2017. Sedangkan sumber data yang digunakan dalam penelitian adalah data sekunder laporan keuangan dan laporan tahunan perusahaan yang diperoleh dari www.idx.co.id.

Pengungkapan emisi karbon merupakan salah satu contoh pengungkapan lingkungan mencakup intensitas gas rumah kaca dan strategi, risiko dan peluang terkait dampak perubahan iklim (Cotter $e t$ al., 2011). Luas pengungkapan emisi karbon diukur dengan menggunakan indeks yang dikembangkan Choi et al. (2013) yang terkonstruksi dari request sheet Carbon Disclosure Project (CDP).

Indeks pengungkapan emisi karbon disajikan pada Tabel 1 .

Tabel 1. Indeks Pengungkapan Emisi Karbon

\begin{tabular}{|c|c|}
\hline Variabel & Indikator \\
\hline $\begin{array}{l}\text { Perubahan iklim : } \\
\text { risiko dan } \\
\text { peluang }\end{array}$ & $\begin{array}{l}\text { CC1 - Penilaian/ deskripsi dari risiko yang berhubungan dengan perubahan iklim dan aksi } \\
\text { yang dilakukan atau aksi yang akan dilakukan untuk mengatasi risiko } \\
\text { CC2 - Penilaian/deskripsi saat ini (dan masa depan) dari implikasi keuangan, implikasi } \\
\text { bisnis, dan peluang dari perubahan iklim }\end{array}$ \\
\hline $\begin{array}{l}\text { Penghitungan } \\
\text { emisi GRK }\end{array}$ & $\begin{array}{l}\text { GHG1 - Deskripsi tentang metodologi yang digunakan untuk mengkalkulasi (menghitung) } \\
\text { emisi GRK (Gas Rumah Kaca) } \\
\text { GHG2 - Keberadaan verifikasi dari pihak eksternal dalam mengukur jumlah emisi GRK } \\
\text { GHG3 - Total emisi GRK yang dihasilkan } \\
\text { GHG4 - Pengungkapan lingkup } 1 \text { dan 2, atau lingkup } 3 \text { emisi GRK } \\
\text { GHG5 - Pengungkapan sumber emisi GRK } \\
\text { GHG6 - Pengungkapan fasilitas atau segmen dari GRK } \\
\text { GHG7 - Perbandingan emisi GRK dengan tahun sebelumnya }\end{array}$ \\
\hline Konsumsi Energi & $\begin{array}{l}\text { EC1 - Total energi yang dikonsumsi } \\
\text { EC2 - Kuantifikasi energi yang digunakan dari sumber terbarukan } \\
\text { EC3 - Pengungkapan menurut tipe, fasilitas atau segmen }\end{array}$ \\
\hline $\begin{array}{l}\text { Biaya dan } \\
\text { pengurangan } \\
\text { GHG }\end{array}$ & $\begin{array}{l}\text { RC1 - Rencana atau strategi detail untuk mengurangi emisi GRK } \\
\text { RC2 - Spesifikasi dari target tingkat/level dan tahun untuk mengurangi emisi GRK } \\
\text { RC3 - Pengurangan emisi dan biaya atau tabungan (costs or savings) yang dicapai saat ini } \\
\text { sebagai akibat dari rencana pengurangan emisi karbon } \\
\text { RC4 - Biaya emisi masa depan yang diperhitungkan dalam perencanaan belanja modal } \\
\text { (capital expenditure planning) }\end{array}$ \\
\hline $\begin{array}{l}\text { Akuntabilitas } \\
\text { Emisi Karbon }\end{array}$ & $\begin{array}{l}\text { ACC1 - indikasi dari dewan komite yang bertanggungjawab atas tindakan yang } \\
\text { berhubungan dengan perubahan iklim } \\
\text { ACC2 - deskripsi dari mekanisme dewan meninjau kemajuan perusahaan mengenai } \\
\text { perubahan iklim }\end{array}$ \\
\hline
\end{tabular}

Sumber: Choi et al., 2013

Formula pengungkapan emisi karbon yang dikembangkan dalam penelitian ini adalah:

$$
C E D=\frac{\Sigma \mathrm{di}}{\mathrm{M}} \times 100 \%
$$

Keterangan:

$$
C E D=\text { pengungkapan emisi karbon / carbon }
$$
emission disclosure

$\Sigma \mathrm{di}=$ total keseluruhan skor 1 yang didapat perusahaan

$\mathrm{M}=$ total item maksimal yang dapat diungkapkan (18 item)

Pengukuran pengungkapan emisi karbon dengan menggunakan indeks CDP telah digunakan oleh beberapa peneliti sebelumnya seperti Alvarez et al. (2015), Saka dan Oshika (2014), serta Matsumura et al. (2014).
Biaya ekuitas merupakan biaya atau tingkat imbal hasil yang dipersyaratkan investor untuk menanamkan modalnya pada perusahaan. Penelitian ini menggunakan model Ohlson untuk mengukur biaya ekuitas karena model tersebut menggunakan data laba per saham dan harga saham yang terkait pertimbangan investor dalam pengambilan keputusan investasi. Rumus mengukur biaya ekuitas sesuai model Ohlson (Botosan, 1997; Ohlson, 1995) yaitu:

$r=\frac{B_{t}+X_{t+1}-P_{t}}{P_{t}}$.....

Keterangan:

$\mathrm{r}$ = biaya ekuitas

$\mathrm{B}_{\mathrm{t}}=$ nilai buku per lembar saham pada saat $\mathrm{t}$

$\mathrm{P}_{\mathrm{t}}=$ harga saham pada saat $\mathrm{t}$

$\mathrm{X}_{\mathrm{t}+1}=$ laba per lembar saham periode $\mathrm{t}+1$ 
Abnormal return adalah selisih antara tingkat keuntungan sebenarnya (actual return) dengan tingkat keuntungan yang diharapkan (expected return). Pengukuran menggunakan cumulative abnormal return (CAR) dianggap lebih akurat karena mempertimbangkan adanya penambahan beta sebagai pertimbangan adanya risiko di dalam melakukan perhitungan return saham. Penelitian ini menggunakan periode pengamatan yaitu 30 hari sebelum dan sesudah publikasi serta 1 hari pada saat laporan tahunan masing-masing perusahaan dipublikasikan. Periode 30 hari dipilih karena investor membutuhkan waktu yang lebih lama untuk bereaksi terkait informasi emisi karbon yang merupakan aspek non keuangan yang sulit diukur nilai ekonomisnya. Untuk mengestimasi hubungan return perusahaan dan return pasar, penelitian ini menggunakan periode estimasi selama 100 hari sebelum periode pengamatan (Ramírez et al., 2016) yaitu dari t-31 hingga hari t -130 .

CAR merupakan jumlah abnormal adjusted return (AR) yang diperoleh menggunakan rumus regresi berikut ini (Combs dan Skill, 2003):

$\mathrm{R}_{\mathrm{it}}=\alpha_{\mathrm{i}}+\beta_{\mathrm{i}} \mathrm{R}_{\mathrm{mt}}+\varepsilon_{\mathrm{it}}$

Keterangan:

$\mathrm{R}_{\mathrm{it}}=$ keuntungan atas sekuritas $i$ pada waktu $t$

$\mathrm{R}_{\mathrm{mt}}=$ keuntungan pasar atas pasar yang telah ditunjuk

$\alpha_{\mathrm{i}}=$ beta saham $i$

$\beta_{\mathrm{i}}=$ konstanta

$\varepsilon_{\mathrm{it}}=$ kesalahan estimasi periode $t$
Kemudian, keuntungan abnormal yang disesuaikan dari suatu perusahaan dihitung menggunakan rumus berikut ini:

$\mathrm{AR}_{\mathrm{it}}=\mathrm{R}_{\mathrm{it}}-\left(\alpha_{\mathrm{i}}+\beta_{\mathrm{i}} \mathrm{R}_{\mathrm{mt}}\right)$

Keterangan:

$\alpha_{\mathrm{i}}$ dan $\beta_{\mathrm{i}}=$ estimasi parameter kuadrat terkecil yang diperoleh dari regresi $R_{i t}$ pada $R_{m t}$ selama periode estimasi

CAR adalah AR kumulatif sesuai dengan yang telah terpilih.

Penelitian menggunakan analisis jalur untuk menguji persamaan struktural berikut:

$\mathrm{y}_{1}=\mathrm{y}_{1} \mathrm{x}_{1}+\varepsilon_{1}$

$\mathrm{y}_{2}=\rho \mathrm{y}_{2} \mathrm{x}_{1}+\rho \mathrm{y}_{2} \mathrm{y}_{1}+\varepsilon_{2}$

Keterangan:

$\mathrm{x}_{1}=$ Pengungkapan Emisi Karbon

$\mathrm{y}_{1}=$ Biaya Ekuitas

$\mathrm{y}_{2}=$ Abnormal Return Saham

$\varepsilon=$ Unexplained variance

\section{HASIL DAN PEMBAHASAN}

Populasi yang digunakan dalam penelitian adalah seluruh perusahaan non-keuangan yang terdaftar di Bursa Efek Indonesia (BEI) dari tahun 2013 sampai 2017. Proses pemilihan sampel berdasarkan kriteria yang telah ditetapkan disajikan dalam Tabel 2.

Tabel 2. Sampel Penelitian

\begin{tabular}{lc}
\hline \multicolumn{1}{c}{ Kriteria } & Jumlah \\
\hline Populasi & 447 \\
Perusahaan Keuangan & $(80)$ \\
$\begin{array}{l}\text { Perusahaan dengan data laporan tahunan tidak lengkap } \\
\text { dan tidak mengungkapkan kebijakan terkait emisi karbon }\end{array}$ & $(245)$ \\
\hline Jumlah Sampel & 122 \\
\hline
\end{tabular}

Sumber: Data diolah, 2018

Perusahaan yang memenuhi kriteria sampel untuk masing-masing tahun berjumlah 122 perusahaan sehingga jumlah unit analisis sebanyak 610 data. Hasil analisis dengan menggunakan software SPSS versi 20 menunjukkan dari total 610 data, terdapat indikasi 142 data mengalami outlier (z-score $\pm 2,58$ ), sehingga tidak digunakan dalam analisis. Dengan demikian, total sampel secara keseluruhan yang digunakan adalah 468 unit analisis.

Uji normalitas diukur berdasarkan distribusi normal dari data dengan mean dan standar deviasi yang sama. Data dikatakan normal apabila hasil dari uji Kolmogorov-Smirnov memiliki tingkat probabilitas signifikansi lebih besar dari 0,05 atau 5 persen (Ghozali, 2012:160). Berikut adalah hasil dari uji normalitas yang disajikan dalam Tabel 3 .

Hasil uji normalitas menunjukkan seluruh model memiliki tingkat signifikansi lebih besar dari 0,05, maka dapat disimpulkan data cenderung terdistribusi normal sehingga model-model regresi layak untuk dilakukan pengujian lebih lanjut.

Analisis statistik deskriptif dilakukan untuk mengetahui deskripsi variabel penelitian yang menggambarkan kondisi perusahaan yang dijadikan 
Tabel 3. Hasil Uji Normalitas

\begin{tabular}{cccccc}
\hline $\begin{array}{c}\text { Variabel } \\
\text { Independen }\end{array}$ & $\begin{array}{c}\text { Variabel } \\
\text { Dependen }\end{array}$ & Model & $\begin{array}{c}\text { Kolmogorov- } \\
\text { Smirnov Z }\end{array}$ & Sig. & Keterangan \\
\hline CED & COE & 1 & 1,167 & 0,131 & Terdistribusi normal \\
CED & CAR & 2 & 0,732 & 0,657 & Terdistribusi normal \\
COE & & &
\end{tabular}

$\mathrm{CED}=$ Carboan Emmission Disclosure (pengungkapan emisi karbon), $\mathrm{COE}=$ Cost of Equity (biaya ekuitas), dan $\mathrm{CAR}=$ Cumulative Abnormal Return (Abnormal return perusahaan)

Sumber: Data diolah, 2018

sampel penelitian secara keseluruhan. Nilai yang dilihat dari statistik deskriptif adalah nilai rata-rata, maksimum, minimum, dan standar deviasi dari variabel-variabel yang diteliti. Hasil statistik deskriptif penelitian disajikan pada Tabel 4.

Tabel 4. Statistik Deskriptif

\begin{tabular}{lccccc}
\hline & $\mathrm{N}$ & Minimum & Maximum & Mean & Std. Deviasi \\
\hline Pengungkapan emisi karbon & 468 & 0,056 & 0,278 & 0,150 & 0,076 \\
Biaya ekuitas & 468 & $-2,876$ & 1,332 & $-0,140$ & 0,643 \\
Abnormal return saham & 468 & $-0,089$ & 0,066 & $-0,012$ & 0,033 \\
\hline
\end{tabular}

Sumber: Data diolah, 2018

Pengungkapan emisi karbon menunjukkan nilai terendah sebesar 0,056 dan nilai tertinggi 0,278, dengan rata-rata pengungkapan 0,150 dan standar deviasi 0,076 . Berarti perusahaan rata- rata mengungkapkan 2- 3 item dari 18 item indeks pengungkapan emisi karbon. Hal ini menunjukkan bahwa kesadaran perusahaan Indonesia untuk mengungkapkan informasi emisi karbon masih rendah. Nilai standar deviasi yang lebih kecil dari nilai rata-rata menunjukkan penyebaran data variabel pengungkapan emisi karbon cukup normal.

Biaya ekuitas pada perusahaan sampel menunjukkan nilai terendah sebesar $-2,876$ dan nilai tertinggi sebesar 1,332, dengan nilai rata-rata sebesar $-0,140$ dan standar deviasi sebesar 0,643. Hal ini menunjukkan rata-rata perusahaan sampel memiliki biaya ekuitas yang negatif yang berarti bahwa sebagian besar investor mengalami kerugian dalam berinvestasi. Nilai standar deviasi yang lebih besar dari nilai rata-rata menunjukkan bahwa penyebaran data untuk variabel biaya ekuitas cenderung tidak normal.

Reaksi investor dalam bentuk Cumulative Abnormal Return (CAR) terendah adalah -0,089 dan tertinggi 0,066 , dengan rata-rata dan standar deviasi sebesar $-0,012$ dan 0,033 . Hal ini berarti ratarata perusahaan non keuangan memperoleh CAR negatif sebesar 1,2 persen. Standar deviasi CAR sebesar 3,3 persen yang lebih besar dari nilai ratarata menunjukkan bahwa tidak sedikit data reaksi investor yang menyimpang dari nilai rata-rata.

Setelah uji kesesuaian model (Goodness-of-Fit Model) terpenuhi, maka peneliti melakukan pengujian terhadap hipotesis dengan menggunakan model regresi dalam analisis jalur untuk memprediksi hubungan antara variabel eksogen dan variabel endogen. Berikut adalah koefisien jalur standardized value yang disajikan dalam Tabel 5.

Tabel 5. Koefisien Jalur Standardized Value

\begin{tabular}{lcccc}
\hline \multicolumn{1}{c}{ Variabel } & Koef. Estimasi & S.E & P & Keterangan \\
\hline $\begin{array}{l}\text { Pengungkapan emisi karbon terhadap biaya } \\
\text { ekuitas }\end{array}$ & $-0,212$ & 0,383 & 0,000 & Signifikan \\
$\begin{array}{l}\text { Pengungkapan emisi karbon terhadap } \\
\text { abnormal return saham }\end{array}$ & 0,049 & 0,020 & 0,292 & Tidak Signifikan \\
$\begin{array}{l}\text { Biaya ekuitas terhadap abnormal return } \\
\text { saham }\end{array}$ & $-0,204$ & 0,002 & 0,000 & Signifikan \\
\hline
\end{tabular}

Sumber: Data diolah, 2018 
Model diagram jalur Tabel 5. digambarkan pada Gambar 2.

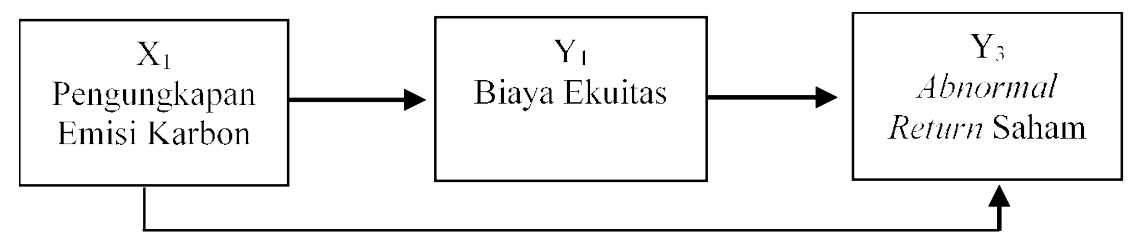

\section{Gambar 2. Model Diagram Jalur Pengaruh Pengungkapan Emisi Karbon Terhadap Biaya Ekuitas dan Abnormal Return Saham}

Sumber: Data diolah, 2018

Diagram jalur Gambar 2 menggambarkan hal berikut: Pengaruh variabel pengungkapan emisi karbon $\left(\mathrm{X}_{1}\right)$ terhadap biaya ekuitas $\left(\mathrm{Y}_{1}\right)$ diperoleh nilai koefisien jalur negatif sebesar $-0,212$ dan $p$ value sebesar 0,000. Hal ini menunjukkan bahwa pengungkapan emisi karbon berpengaruh negatif dan signifikan terhadap biaya ekuitas. Pengaruh variabel pengungkapan emisi karbon $\left(\mathrm{X}_{1}\right)$ terhadap abnormal return saham $\left(\mathrm{Y}_{2}\right)$ diperoleh nilai koefisien jalur positif sebesar 0,049 dan $p$ value sebesar 0,292. Hal ini menunjukkan bahwa pengungkapan emisi karbon berpengaruh positif tetapi tidak signifikan terhadap abnormal return saham. Pengaruh variabel biaya ekuitas $\left(\mathrm{Y}_{1}\right)$ terhadap abnormal return saham $\left(\mathrm{Y}_{2}\right)$ diperoleh nilai koefisien jalur negatif sebesar -0,204 dan $p$ value sebesar 0,000 . Hal ini menunjukkan bahwa biaya ekuitas berpengaruh negatif dan signifikan terhadap abnormal return saham.

Penelitian juga menggunakan pengujian Sobel (Sobel Test) untuk menguji pengaruh tidak langsung atau peran mediasi biaya ekuitas pada hubungan pengungkapan emisi karbon terhadap abnormal return saham. Hasil perhitungan pengujian sobel disajikan pada Tabel 6.

Tabel 6. Hasil Perhitungan Pengujian Sobel

\begin{tabular}{|c|c|c|c|}
\hline \multirow[t]{2}{*}{ Kombinasi Variabel } & Nilai & Standard & $p$ value of \\
\hline & Estimasi & Error & Sobel Test \\
\hline $\begin{array}{l}\text { Pengaruh pengungkapan emisi karbon } \\
\text { terhadap abnormal return saham } \\
\text { melalui biaya ekuitas }\end{array}$ & $-1,793 ;-0,011$ & 0,$383 ; 0,002$ & 0,000 \\
\hline
\end{tabular}

Sumber: Data diolah, 2018

Hasil perhitungan Sobel test Tabel 6 menunjukkan bahwa pengaruh tidak langsung pengungkapan emisi karbon terhadap abnormal return saham memiliki nilai $p$-value Sobel sebesar $0,000<0,05$. Dengan demikian variabel biaya ekuitas dalam penelitian ini merupakan tipe Full Mediation sehingga dapat disimpulkan variabel biaya ekuitas berperan memediasi hubungan pengungkapan emisi karbon terhadap abnormal return saham.

Hasil perhitungan pengujian hipotesis disajikan pada Tabel 7.

Tabel 7. Pengujian Hipotesis

\begin{tabular}{lc}
\hline \multicolumn{1}{c}{ Variabel } & $\begin{array}{c}\text { Hasil Pengujian } \\
\text { Hipotesis }\end{array}$ \\
\hline $\mathrm{H}_{1}$ : Pengaruh pengungkapan emisi karbon terhadap biaya ekuitas & Diterima \\
$\mathrm{H}_{2}$ : Pengaruh pengungkapan emisi karbon terhadap abnormal return saham & Ditolak \\
$\mathrm{H}_{3}$ : Pengaruh biaya ekuitas terhadap abnormal return saham & Diterima \\
$\mathrm{H}_{4}$ : Biaya ekuitas memediasi hubungan pengungkapan emisi karbon terhadap abnormal & Diterima \\
return saham &
\end{tabular}

Sumber: Data diolah, 2018

Hasil uji pengaruh variabel pengungkapan emisi karbon terhadap biaya ekuitas perusahaan menunjukkan nilai koefisien regresi sebesar -0,212 dan nilai probabilitas signifikansi sebesar 0,000 , sehingga dapat disimpulkan bahwa pengungkapan emisi karbon memiliki pengaruh negatif dan signifikan 
terhadap biaya ekuitas perusahaan. Dengan demikian Hipotesis $1\left(\mathrm{H}_{1}\right)$ yang menyatakan bahwa pengungkapan emisi karbon berpengaruh signifikan terhadap biaya ekuitas diterima.

Teori sinyal menyatakan semakin luas pengungkapan informasi yang disampaikan maka semakin kecil tingkat risiko yang dihasilkan (Spence, 1973). Pengungkapan emisi karbon yang tinggi seperti pengungkapan rencana atau strategi detail untuk mengurangi emisi karbon dan penghematan energi yang dilakukan perusahaan dapat menjadi goodnews bagi investor bahwa risiko investasi di perusahaan rendah. Investor juga cenderung merespon sesuatu yang baik dalam konteks sustainability karena kesadaran peduli lingkungan merupakan tanggungjawab semua komponen bumi. Oleh karena itu, kepercayaan investor meningkat dan cenderung mendorong investor melakukan investasi lebih besar sehingga harga saham perusahaan naik dan menghasilkan biaya ekuitas perusahaan yang rendah.

Hasil penelitian konsisten dengan penelitian Michaels dan Grüning (2017), Kelvin et al. (2017) serta Gupta (2018) yang menyatakan perusahaan dengan pengungkapan lingkungan tinggi akan menikmati biaya ekuitas yang lebih rendah. Pengungkapan emisi karbon merupakan pilihan rasional perusahaan untuk mengurangi tekanan yang diberikan oleh ancaman legitimasi sehingga mampu menurunkan biaya ekuitas perusahaan.

Hasil uji pengaruh variabel pengungkapan emisi karbon terhadap abnormal return saham menunjukkan nilai koefisien regresi sebesar 0,049 dan nilai probabilitas signifikansi sebesar 0,292 , sehingga dapat disimpulkan bahwa pengungkapan emisi karbon memiliki pengaruh positif tetapi tidak signifikan terhadap abnormal return saham. Dengan demikian Hipotesis $2\left(\mathrm{H}_{2}\right)$ yang menyatakan bahwa pengungkapan emisi karbon berpengaruh signifikan terhadap abnormal return saham ditolak.

Bisnis yang berkelanjutan tentu dapat terpenuhi apabila perusahaan dapat mensejahterakan seluruh stakeholder (Freeman, 1984). Setiap perusahaan diharapkan memiliki kesadaran untuk menjaga dan melestarikan lingkungan hidup yang bukan sematamata demi kepentingan manusia, tetapi merupakan bagian dari tanggung jawab sistem kosmik kehidupan global bumi (Lovelock, 1979). Oleh karena itu, pengungkapan emisi karbon dapat menjadi sinyal yang baik bagi stakeholder bahwa perusahaan turut berkomitmen menjaga kondisi kehidupan bumi dari ancaman perubahan iklim.

Sistem dan kontrol ketat dari mekanisme dewan terhadap manajemen kontrol lingkungan yang sustainable dapat menjadi sinyal yang meyakinkan investor untuk melakukan investasi, sehingga investor dapat memberikan respon positif dari informasi emisi karbon yang diberikan oleh perusahaan dalam bentuk melakukan investasi saham. Dengan demikian, kemampuan berkelanjutan perusahaan di masa yang akan datang mengakibatkan pasar menjadi tidak efisien dan terjadi kenaikan harga saham yang melebihi return yang diekpektasikan oleh investor (abnormal return saham).

Hasil penelitian tidak sejalan dengan penelitian Ramírez et al. (2016) dan Liesen et al. (2017) yang menemukan hubungan positif dan signifikan antara pengungkapan karbon dan abnormal return saham Hasil penelitian ini juga tidak konsisten dengan Li dan $\mathrm{Wu}$ (2017) yang menemukan bahwa pengumuman ramah lingkungan perusahaan China berhubungan negatif signifikan terhadap return saham.

Penelitian menunjukkan pengaruh pengungkapan emisi karbon yang kurang kuat terhadap abnormal return saham. Hal ini mengindikasikan reaksi investor dalam bentuk abnormal return saham cenderung sangat dipengaruhi oleh persepsi investor atas perhitungan yang dilakukan secara ekonomi/ teknikal. Dalam analisis teknikal, Ng dan Daromes (2016) menyatakan investor cenderung lebih percaya pada hitungan angka dan kadangkala tidak mempertimbangkan informasi karbon yang merupakan aspek non keuangan yang bersifat deskriptif. Investor juga cenderung tidak langsung bereaksi bila pengungkapan emisi karbon hanya sekali dilakukan, tetapi membutuhkan aksi yang konsisten selama beberapa tahun.

Hasil uji pengaruh variabel biaya ekuitas terhadap abnormal return saham menunjukkan nilai koefisien regresi sebesar -0,204 dan nilai probabilitas signifikansi 0.000 , sehingga dapat disimpulkan bahwa biaya ekuitas memiliki pengaruh negatif dan signifikan terhadap abnormal return saham. Dengan demikian Hipotesis $3\left(\mathrm{H}_{3}\right)$ yang menyatakan bahwa biaya ekuitas berpengaruh signifikan terhadap abnormal return saham diterima.

Manajemen perusahaan dapat mengelola seluruh sumber daya yang dimiliki perusahaan melalui strategi dan operasi perusahaan yang berpotensi membawa 
manfaat ekonomi pada stakeholder seperti berinvestasi di energi alternatif terbarukan yang mengurangi emisi karbon. Apabila seluruh sumber daya yang dimiliki perusahaan dapat dikelola dan dimanfaatkan dengan baik maka akan menciptakan nilai bagi perusahaan, sehingga dapat meningkatkan kesejahteraan stakeholder (Harrison dan Wicks, 2013). Kesejahteraan yang meningkat diwujudkan dengan meningkatnya return perusahaan

Prospek perusahaan yang baik akan membuat risiko investasi yang ditanggung investor menjadi lebih rendah yang membuat permintaan biaya ekuitas akan menjadi rendah. Investor cenderung lebih meminati saham yang memiliki laba per saham tinggi dibandingkan saham yang memiliki laba per saham rendah. Perusahaan yang memiliki laba per saham yang tinggi akan mendapatkan penambahan investasi dan membuat biaya ekuitas menurun. Penurunan dari biaya ekuitas akan meningkatkan abnormal return yang merupakan selisih antara actual return dengan expected return yang mencerminkan biaya ekuitas.

Hasil penelitian sejalan dengan penelitian Li et al. (2013) yang menyatakan biaya ekuitas berpengaruh signifikan terhadap tingkat pengembalian yang diharapkan investor. Namun, hasil penelitian tidak sejalan dengan Larocque dan Lyle (2017) yang tidak menemukan adanya hubungan antara biaya ekuitas dan return saham di masa mendatang. Biaya ekuitas dipandang tidak memberikan informasi return saham secara inkremental karena kurangnya hubungan dengan return akuntansi masa depan.

Hasil penelitian juga menunjukkan bahwa variabel biaya ekuitas memiliki peran dalam memediasi pengungkapan emisi karbon terhadap abnormal return saham. Nilai koefisien pengaruh tidak langsung pengungkapan emisi karbon terhadap abnormal return saham melalui biaya ekuitas sebesar 0,043 dengan $p$-value Sobel test sebesar $0,000<$ alpha 0,05 . Hal ini menunjukkan bahwa biaya ekuitas memediasi secara penuh hubungan pengungkapan emisi karbon terhadap abnormal return saham. Dengan demikian Hipotesis $4\left(\mathrm{H}_{4}\right)$ yang menyatakan bahwa biaya ekuitas memediasi hubungan pengungkapan emisi karbon dan abnormal return saham diterima.

Konsisten dengan teori stakeholder, nasib dan kelangsungan hidup ekosistem alam serta kondisi kehidupan generasi sekarang dan mendatang sangat dipengaruhi oleh aktivitas bisnis yang dijalankan oleh perusahaan (Zsolnai, 2006). Setiap perusahaan diharapkan memiliki kesadaran untuk menjaga dan melestarikan lingkungan hidup yang bukan sematamata demi kepentingan manusia, tetapi merupakan bagian dari tanggung jawab sistem kehidupan di bumi (Lovelock, 1979). Oleh karena itu, pengungkapan emisi karbon dapat menjadi sinyal yang baik bagi stakeholder bahwa perusahaan turut berkomitmen menjaga kondisi kehidupan bumi dari ancaman perubahan iklim.

Sistem kontrol dan manajemen lingkungan perusahaan yang berkualitas dapat menjadi sinyal yang meyakinkan investor bahwa perusahaan telah mengelola investasi yang telah diberikan dengan baik. Hal ini mengindikasikan pengungkapan emisi karbon mampu memengaruhi persepsi stakeholder bahwa perusahaan memiliki risiko investasi rendah. Dengan demikian, hal ini akan mendorong investor untuk menurunkan biaya ekuitas karena kinerja perusahaan yang baik mengartikan risiko investasi yang rendah. Biaya ekuitas yang rendah tentu menjadi sinyal positif bahwa imbal hasil yang didapatkan investor akan semakin meningkat. Hal ini mengakibatkan investor maupun investor potensial ingin menanamkan modal di perusahaan, sehingga terjadi kenaikan harga saham yang melebihi return yang diekpektasikan oleh investor (abnormal return saham).

\section{SIMPULAN}

Penelitian dilakukan dengan tujuan untuk menguji hubungan pengungkapan emisi karbon dan abnormal return saham yang dimediasi oleh biaya ekuitas. Berdasarkan analisis data yang telah dilakukan sebelumnya, maka kesimpulan yang dapat dihasilkan dari penelitian ini adalah sebagai berikut: (1) pengungkapan emisi karbon memiliki pengaruh negatif dan signifikan terhadap biaya ekuitas. (2) Pengungkapan emisi karbon memiliki pengaruh positif tetapi tidak signifikan terhadap abnormal return saham. (3) Biaya ekuitas memiliki pengaruh negatif dan signifikan terhadap abnormal return saham. (4) Biaya ekuitas berperan dalam memediasi pengungkapan emisi karbon terhadap abnormal return saham.

Respon terhadap ancaman yang ditimbulkan dari perubahan iklim telah menjadi perhatian dari berbagai dunia dan menjadi bagian integral dari bisnis. Kondisi suhu bumi yang semakin meningkat akibat gas rumah kaca dapat memicu bumi untuk segera melakukan pemusnahan massal dan membentuk ekosistem baru yang lebih stabil. Namun, bumi sendiri tidak menjamin bahwa manusia sebagai makhluk yang paling berkuasa 
dapat lolos dari pemusnahan yang akan terjadi di kemudian hari. Oleh karena itu, kesadaran akan pentingnya menjaga kelestarian lingkungan hidup merupakan tanggungjawab seluruh makhluk yang ada di bumi untuk bersama-sama berkontribusi menjaga kondisi bumi agar tetap layak ditinggali.

Implikasi teoretis penelitian ini menguatkan teori stakeholder yang dikemukakan oleh Freeman dan Reed (1983), Donaldson dan Preston (1995), Harrison dan Wicks (2013), dan Zsolnai (2006) yang menjelaskan bahwa perusahaan yang baik akan membangun kode etik yang tidak hanya mementingkan kepentingan shareholder namun juga memerhatikan kesejahteraan stakeholder dan lingkungan. Pengungkapan emisi karbon dapat menjadi suatu corporate action yang baik dalam rangka menjaga keseimbangan sistem kehidupan yang ada di Bumi. Hasil penelitian juga sejalan dengan teori Gaia bahwa perusahaan dan seluruh makhluk memiliki kewajiban untuk menjaga dan melestarikan lingkungan hidup yang bukan demi kepentingan manusia saja, tetapi juga harus menghormati unsur pendukung bumi yang lain, seperti tanah, udara, lautan, dan semua komponennya baik yang hidup maupun tidak (Lovelock, 1979).

Penelitian juga menguatkan teori sinyal yang dikemukakan oleh Spence (1973) bahwa pengungkapan emisi karbon dapat memberikan goodnews bagi investor bahwa perusahaan telah mengelola investasi yang telah diberikan dengan baik. Para investor akan yakin bahwa investasi yang diberikan pada perusahaan tidak sia-sia karena perusahaan memiliki risiko lingkungan yang rendah dan senantiasa menjaga nama baiknya sebagai perusahaan ramah lingkungan. Dengan demikian, harga saham diharapkan semakin yang melebihi return yang diekpektasikan oleh investor (abnormal return saham).

Penelitian ini juga memiliki implikasi praktis bagi perusahaan bahwa pengungkapan emisi karbon dapat menjadi salah satu bentuk sumbangsih perusahaan untuk ikut serta menjaga harmoni sistem kehidupan yang ada di bumi karena tingkat karbondioksida yang semakin meningkat juga merupakan akibat dari perkembangan industri yang semakin pesat. Dengan demikian, perusahaan diharapkan dapat memerhatikan hubungan perusahaan dengan lingkungan sekitarnya karena pengungkapan atas pengurangan emisi karbon yang dilakukan perusahaan akan dinilai sebagai tanda keseriusan perusahaan menangani masalah pemanasan global (efek gas rumah kaca).
Penelitian ini memiliki keterbatasan yang perlu diperhatikan oleh peneliti selanjutnya dalam rangka mengembangkan penelitian ini, yaitu pengukuran pengungkapan emisi karbon hanya berasal dari laporan tahunan karena tidak semua perusahaan menerbitkan laporan keberlanjutan sebagai sumber lain pengungkapan lingkungan dan penelitian ini juga tidak menggunakan variabel kontrol dalam mengontrol industrial effect antara perusahaan dengan berbagai karakteristik yang berbeda seperti jumlah aset yang besar dengan perusahaan dengan jumlah aset yang lebih kecil. Penelitian yang akan datang sebaiknya mempertimbangkan penggunaan variabel kontrol agar dapat memberikan penjelasan yang lebih baik atas hubungan antar variabel serta mempertimbangkan variabel kinerja karbon agar dapat memberikan bukti bahwa pengungkapan emisi karbon bukan hanya sebatas pencitraan tetapi kesadaran yang tinggi dari perusahaan untuk menjaga keseimbangan dan keberlanjutan ekosistem alam.

\section{REFERENSI}

Alvarez, I. G., Segura, L., \& Martínez-ferrero, J. (2015). Carbon Emission Reduction: The Impact on the Financial and Operational Performance of International Companies. Journal of Cleaner Production, 103, 149-159.

Botosan, C. A. (1997). Disclosure Level and the Cost of Equity Capital. Accounting Review, 72, 323-349.

Choi, B. B., Lee, D., \& Psaros, J. (2013). An Analysis of Australian Company Carbon EmissionDisclosures. Pacific Accounting Review, 25(1), 58-79.

Combs, J. G., \& Skill, M. S. (2003). Managerialist and Human Capital Explanations for Key Executive Pay Premiums: A Contingency Perspective. Academy of Management Journal, 46(1), 63-73.

Cordeiro, J. J., \& Tewari, M. (2015). FirmCharacteristics, Industry Context, and Investor Reactions to Environmental CSR: A Stakeholder Theory Approach. Journal of Business Ethics, 130(4), 833-849.

Cotter, J., Najah, M., \& Wang, S. S. (2011). Standardized Reporting of Climate Change Information in Australia. Sustainability Accounting, Management and Policy Journal, 2(2), 294-321.

Dhaliwal, D. S., Li, O. Z., Tsang, A., \& Yang, Y. G. (2011). Voluntary Nonfinancial Disclosure and the Cost of Equity Capital: The Initiation of Corporate Social Responsibility Reporting. Accounting Review, 86(1), 59-100. 
Donaldson, T., \& Preston, L. E. (1995). The Stakeholder Theory of the Corporation/ : Concepts , Evidence, and Implications. The Academy of Management Review, 20(1), 65-91.

Freeman, R. E. (1984). Strategic Management: A Stakeholder Approach. Boston, MA: Pitman.

Freeman, R. E., \& Reed, D. L. (1983). Stockholders and Stakeholders: A New Perspective on Corporate Governance. California Management Review, 25(3), 88-106.

Ghozali, I. (2012). Aplikasi Analisis Multivariat dengan Program IBM SPSS 20 Edisi 6. Semarang: Badan Penerbit Universitas Diponegoro.

Gray, R. (2010). Is Accounting for Sustainability Actually Accounting for Sustainability and How Would We Know? An Exploration of Narratives of Organisations and the Planet. Accounting, Organizations and Society, 35(1), 47-62.

Gray, R., Kouhy, R., \& Lavers, S. (1995). Corporate Social and Environmental Reporting: A Review of the Literature and A Longitudinal Study of UK Disclosure. Accounting, Auditing \& Accountability Journal, 8(2), 47-77.

Gupta, K. (2018). Environmental Sustainability and Implied Cost of Equity: International Evidence. Journal of Business Ethics, 147(2), 343-365.

Harrison, J. S., \& Wicks, A. C. (2013). Stakeholder Theory, Value, and Firm Performance. Business Ethics Quarterly, 23(1), 97-124.

Kelvin, C., Daromes, F., \& Ng, S. (2017). Pengungkapan Emisi Karbon sebagai Mekanisme Peningkatan Kinerja untuk Menciptakan Nilai Perusahaan. Dinamika Akuntansi Keuangan Dan Perbankan, 6(1), 1-18. Retrieved from https://www.unisbank .ac.id/ojs/index.php/fe9/article/view/5948

Lambert, R., Leuz, C., \& Verrecchia, R. E. (2007). Accounting Information, Disclosure, and the Cost of Capital. Journal of Accounting Research, 45(2), 385-420.

Larocque, S., \& Lyle, M. R. (2017). Implied Cost of Equity Capital Estimates as Predictors of Accounting Returns and Stock Returns. Journal of Financial Reporting Spring 2017, 2(1), 69-93.

Li, B., \& Wu, K. (2017). The Price of Environmental Sustainability: Empirical Evidence from Stock Market Performance in China. Sustainability (Switzerland), 9(8), 1-16.
Li, Y., Ng, D. T., \& Swaminathan, B. (2013). Predicting Market Returns Using Aggregate Implied Cost of Capital. Journal of Financial Economics, 110(2), 419-436.

Liao, L., Luo, L., \& Tang, Q. (2015). Gender Diversity, Board Independence, Environmental Committee and Greenhouse Gas Disclosure. British Accounting Review, 47(4), 409-424.

Liesen, A., Figge, F., Hoepner, A., \& Patten, D. M. (2017). Climate Change and Asset Prices: Are Corporate Carbon Disclosure and Performance Priced Appropriately? Journal of Business Finance and Accounting, 44(1-2), 35-62.

Lovelock, J. E. (1979). Gaia: A New Look at Life on Earth. Oxford: Oxford University Press.

Matsumura, E. M., Prakash, R., \& Vera-Muñoz, S. C. (2014). Firm-Value Effects of Carbon Emissions and Carbon Disclosures. Accounting Review, 89(2), 695-724.

Meng, X. H., Zeng, S. X., Shi, J. J., Qi, G. Y., \& Zhang, Z. B. (2014). The Relationship Between Corporate Environmental Performance and Environmental Disclosure: An Empirical Study in China. Journal of Environmental Management, 145, 357-367.

Michaels, A., \& Grüning, M. (2017). Relationship of Corporate Social Responsibility Disclosure on Information Asymmetry and the Cost of Capital. Journal of Management Control, 28(3), 251-274.

Ng, S., \& Daromes, F. E. (2016). Peran Kemampuan Manajerial Sebagai Mekanisme Peningkatan Kualitas Laba dan Nilai Perusahaan. Jurnal Akuntansi Dan Keuangan Indonesia, 13(2), 174-193. https://doi.org/10.21002/jaki.2016.10

Odriozola, M. D., \& Baraibar-Diez, E. (2017). Is Corporate Reputation Associated with Quality of CSR Reporting? Evidence from Spain. Corporate Social Responsibility and Environmental Management, 24(2), 121-132.

Ohlson, J. A. (1995). Earnings, Book Values, and Dividends in Equity Valuation. Contemporary Accounting Research, 11(2), 661-687.

Park, J., Lee, H., \& Kim, C. (2014). Corporate Social Responsibilities, Consumer Trust and Corporate Reputation: South Korean Consumers' Perspectives. Journal of Business Research, 67, 295-302.

Ramírez, C. Z., González-González, J. M., \& SabaterMarcos, A. (2016). Carbon Reporting/: Analysis of the Spanish Market Response. Spanish Journal of Finance and Accounting, 45(2), 231-265. 
Saka, C., \& Oshika, T. (2014). Disclosure Effects, Carbon Emissions and Corporate Value. Sustainability Accounting, Management and Policy Journal, 5(1), 22-45.

Spence, M. (1973). Job Market Signaling. The Quarterly Journal of Economics, 87(3), 355-374.

Tempo.co. (2013). 25 Perusahaan Ini Masuk Kategori Pro Lingkungan. Retrieved April 1, 2018, from https://m.tempo.co/read/news/2013/ 08/01/095501662/25-perusahaan-ini-masukkategori-pro-lingkungan

Tribunnews.com. (2017). Lima Tahun Terakhir, Indeks SRI-KEHATI Tumbuh 52,27 Persen. Retrieved April 1, 2018, from http://www. tribunnews.com/bisnis/2017/11/08/produkreksadana-terbaru-rhb-asset-managementusung-konsep-investasi-berkelanjutan

Zsolnai, L. (2006). Extended stakeholder theory. Society and Business Review, 1(1), 37-44. 